\title{
KONDISI FISIK ATLET ANGGAR KOTA SURAKARTA
}

\author{
Agus Supriyoko ${ }^{1}$ dan Wisnu Mahardika ${ }^{2}$ \\ 1,2Universitas Tunas Pembangunan Surakarta \\ Email: agussupriyoko@rocketmail.com ${ }^{1}$,wisnu.mahardika@gmail.com² \\ Diterima: 11 Oktober 2018; Lolos: 27 November 2018; Dipublikasikan: 28 November 2018 \\ DOI: https://doi.org/10.29407/js_unpgri.v4i2.12540
}

\begin{abstract}
Abstrak
Kondisi fisik merupakan komponen terpenting dalam pencapaian prestasi. Kondisi fisik ialah hal mutlak yang wajib dimiliki oleh atlet di dalam mengembangkan dan meningkatkan prestasi olahraga yang optimal, sehingga segenap kondisi fisiknya harus dikembangkan dan ditingkatkan sesuai karakteristik dan kebutuhan masing-masing cabang olahraga. Tujuan dari penelitian ini adalah untuk mengukur kondisi fisik atlet anggar. Populasi dalam penelitian ini adalah seluruh atlet anggar Kota Surakarta yang berjumlah 34 atlet. Data diperoleh melalui tes dan pengukuran dengan item tes:1) tes daya tahan, 2) tes kecepatan, 3) tes kecepatan reaksi, dan 4) dan kekuatan otot tungkai. Hasil penelitian menunjukkan bahwa sebanyak $2(6 \%)$ atlet pada kategori sangat baik, $4(12 \%)$ atlet pada kategori baik, 22 (64\%) atlet pada kategori sedang, 5 (15\%) atlet pada kategori kurang, dan 1 (3\%) atlet pada kategori kurang sekali. Kesimpulan, kondisi fisik atlet anggar Kota Surakarta pada kategori sedang.
\end{abstract}

Kata kunci: Kondisi fisik, anggar, daya tahan, kecepatan, kecepatan reaksi, kekuatan.

\section{PHYSICAL CONDITIONS OF THE FENCING ATHLETE OF SURAKARTA CITY}

\begin{abstract}
Physical condition is the most important component in achievement. Physical condition is an absolute thing that must be possessed by athletes in developing and improving optimal sports performance, so that all their physical conditions must be developed and improved according to the characteristics and needs of each sport. The purpose of this study was to measure the physical condition of fencing athletes. The population in this study were all Surakarta City fencing athletes totaling 34 athletes. Data is obtained through tests and measurements with test items: 1) endurance test, 2) speed test, 3) reaction speed test, and 4) and leg muscle strength. The results showed that 2 (6\%) athletes in the excellent category, 4 (12\%) athletes in the good category, 22 (64\%) athletes in the moderate category, 5 (15\%) athletes in the less category, and 1 (3\%) athletes in the category are very few. Conclusion, the physical condition of Surakarta City fencing athletes in the medium category.
\end{abstract}

Keywords: Physical condition, fencing, endurance, speed, reaction speed, strength.

\section{PENDAHULUAN}

Hakikat olahraga merupakan kegiatan fisik yang mengandung sifat permainan dan berisi perjuangan melawan diri sendiri atau dengan orang

Email : agussupriyoko@rocketmail.com

No Handphone : 081567622330
(C) 2018 UN PGRI Kediri

p-ISSN: 2548-7833

e-ISSN: $2477-3379$ 
lain atau konfrontasi dengan unsur-unsur alam (Pujianto, 2015). Olahraga merupakan salah satu latihan fisik yang baik untuk menjaga dan meningkatkan kebugaran jasmani. Kebugaran jasmani adalah kemampuan seseorang dalam menjalankan jenis kegiatan fisik yang memerlukan kekuatan, daya tahan, dan fleksibilitas (Pratiwi, Setijono, \& Fuad, 2018). Olahraga merupakan kegiatan jasmani yang dilakukan dengan maksud untuk memelihara kesehatan dan memperkuat otot - otot tubuh. Kegiatan ini dalam perkembangannya dapat dilakukan sebagai kegiatan yang menghibur, menyenangkan atau juga dilakukan dengan tujuan untuk meningkatkan prestasi. Tercapainya prestasi olahraga merupakan usaha yang dapat diperhitungkan secara matang melalui pembinaan dini, penguasaan kemampuan teknik, taktik, dan strategi serta melalui berbagai pendekatan (Pujianto, 2015).

Anggar merupakan cabang olahraga yang dapat dilakukan oleh laki-laki maupun perempuan. Pada zaman purbakala sebelum ada senjata modern, setiap bangsa sudah beranggar untuk membela diri dengan menangkis ataupun menyerang. Yang dipergunakan adalah barang apapun juga, baik dari kayu maupun dari besi untuk menangkis bila mendapat serangan (Kurniawan, 2010). Anggar merupakan cabang olahraga yang memiliki karakteristik penekanan pada ketangkasan dengan senjata. Selain itu, cabang olahraga anggar menuntut para pelakunya untuk memiliki kelincangan tangan. Ada 3 jenis senjata digunakan dalam olahraga anggar yaitu sabel, floret, degen. Selain menggunakan senjata,dalam cabang olahraga anggar juga menggunakan seperangkat alat pada berlatih dan bertanding seperti masker untuk melindungi kepala,baju anggar lengkapdengan flastron (pelindung dada) dan breast (untuk perempuan sebagai pelindung dada) dengan tujuan untuk melindungi tubuh dari tusuk senjata, glove atau handsgum atau sarung tangan, body metallic (baju anggar yang bisa dialiri aliran listrik) sebagai perkenaan yang sah pada jenis senjata floret dan sabel. Wire yaitu kabel yang menghubungkan antara senjata dengan rolling-recording dengan cara kabel dimasukkan ke dalam baju anggar dengan melewati 
badan, rolling (kabel gulung yang menghubungkan aliran listrik dari body wire ke recording) dan recording yaitu alat pencatat skor digital dari hasil perkenaan tusukan pemain anggar.

Cabang olahraga anggar kota Surakarta merupakan salah satu daerah yang ada di Jawa Tengah yang mempunyai prestasi sangat baik. Hal ini terbukti pada setiap kejuaraan di Jawa Tengah, kota Surakarta selalu meraih juara umum. Selain itu pada Pekan Olahraga Provinsi (PORProv) tahun 2009, cabang olahraga anggar kota Surakarta berhasil meraih 6 emas, 1 perak, 3 perunggu. Hal ini terulang lagi pada PORProv tahun 2013 di Banyumas. Kontingen kota Surakarta mendapat 7 emas, 3 perak, dan 3 perunggu sehingga menjadi juara umum kembali. Selain itu untuk ditingkat nasional atlet anggar dari kota Surakarta sudah mampu menembus 4 besar, suatu hasil yang membanggakan. Pada tahun 2015, 2 atlet anggar dari kota Surakarta mengikuti Training Center (TC) Pelatihan Nasional (PELATNAS) untuk mengikuti Sea Games 2015. Hendra Faradillah adalah pelatih anggar di Kota Surakarta sekaligus mantan atlet Nasional yang sudah beberapa kali mengikuti PELATNAS dan mempunyai prestasi yang membanggakan tidak menutup kemungkinan atlet yang dibinanya juga bisa mengikuti jejak beliau.

Pencapaian prestasi cabang olahraga anggar kota Surakarta tentunya tidak terlepas dari berbagai faktor, salah satunya adalah faktor kondisi fisik. Fisik merupakan pondasi dari prestasi olahraga sebab teknik, taktik dan mental akan dapat dikembangkan dengan baik jika memiliki kualitas fisik yang baik (Hinda Zhannisa \& Sugiyanto, 2015). Kondisi fisik merupakan suatu persyaratan yang harus dimiliki oleh seorang atlet di dalam meningkatkan dan mengembangkan prestasi olahraga yang optimal, sehingga segenap kondisi fisiknya harus dikembangkan dan ditingkatkan sesuai dengan ciri, karakteristik, dan kebutuhan masingmasing cabang olahraga (Pujianto, 2015). Physical condition is a necessary requirement in improving an athlete's performance, and may even be regarded as a basic necessity that cannot be postponed or negotiable (Hanief, Puspodari, \& Sugito, 2017). yang 
memiliki arti "Kondisi fisik merupakan kebutuhan yang diperlukan dalam meningkatkan kinerja atlet, dan bahkan dapat dianggap sebagai kebutuhan dasar yang tidak dapat ditunda atau dinegosiasikan". Kondisi fisik adalah salah satu prasyarat yang sangat diperlukan dalam setiap usaha peningkatan prestasi seorang atlit, bahkan dapat dikatakan dasar landasan titik tolak suatu awalan olahraga prestasi (Pratama, 2015). Dari beberapa pendapat tersebut dapat disimpulkan bahwa kondisi fisik merupakan apek yang sangat penting sebagai penunjang pencapaian prestasi seorang atlet, sehingga faktor kondisi fisik harus diperhatikan oleh atlet.

Berdasarkan uraian di atas, peneliti tertarik untuk mengukur sekaligus mengetahui bagaimana kondisi fisik atlet anggar kota Surakarta. Penelitian serupa juga telah dilakukan oleh Pertiwi (2012) yang berjudul "Profil Kondisi Fisik Atlet Anggar di Kabupaten Purworejo Jawa Tengah" dengan kesimpulan hasil keseluruhan putra dan putri: Baik Sekali 0\% (0 orang), Baik 0\% (0 orang), Sedang 40\% (8 orang), Kurang 55\% (11 orang), dan Kurang Sekali 5\% (1 orang). Sedangkan untuk hasil tes kondisi fisik khusus (terkait keterampilan) cabang olahraga anggar secara keseluruhan putra dan putri: Baik Sekali 0\% (0 orang), Baik 5\% (1 orang), Sedang 60\% (12 orang), Kurang 35\% (7 orang), Kurang Sekali 0\% (0 orang). Hasil penelitian tersebut dilakukan pada atlet anggar Kabupaten Purworejo pada tahun 2012 yang mana jika dilihat dari data prestasi pada PORProv 2013, Kabupaten Purworejo berada dibawah kota Surakarta pada klasemen perolehan medali. Hal ini berarti, penelitian yang dilakukan sama, akan tetapi hasil penelitian ini tentunya berbeda jika dipandang dari sudut kualitas atlet kota Surakarta yang mampu meraih juara umum pada tahun 2013. Secara kualitas, atlet anggar kota Surakarta tahun 2013 lebih unggul dari atlet Kabupaten Purworejo.

Hasil penelitian ini pun nanti akan menghasilkan norma baru pada kondisi fisik atlet anggar yang diperoleh dari atlet berprestasi, sehingga norma tersebut dapat digunakan sebagai acuan ke depannya. Masalah ini sangat menarik untuk diteliti karena belum banyak yang melakukan 
penelitian tentang norma tes untuk kemampuan fisik seorang atlet khususnya cabang anggar.

\section{METODE}

Jenis penelitian ini adalah deskriptif kuantitatif, yang mendeskrisikan fenomena tertentu. Populasi dalam penelitian ini adalah seluruh atlet anggar Surakarta, dengan jumlah 34 atlet. Teknik pengambilan sampel menggunakan teknik total sampling, yaitu teknik penentuan sampel dengan mengambil seluruh anggota populasi sebagai responden atau sampel (Sugiyono, 2011). Teknik pengumpulan data dalam penelitian ini menggunakan tes dan pengukuran. Pengumpulan data dalam pelaksanaan penelitian ini adalah menggunakan sebagai berikut: 1) tes daya tahan dengan shadow fencing, 2) tes kecepatan dengan step test, 3) tes kecepatan reaksi dengan kecepatan reaksi tusukan, dan 4) tes kekuatan otot tungkai dengan split squat jump test. Analisis data yang digunakan adalah Analisis untuk mencari reliabilitas tes-retes dengan menggunakan Anava (metode Analisis of Variance), kemudian mencari T-Score, menyusun norma dan menetapkan kategori norma menjadi 5 kategori. Kurva norma sebagai berikut:

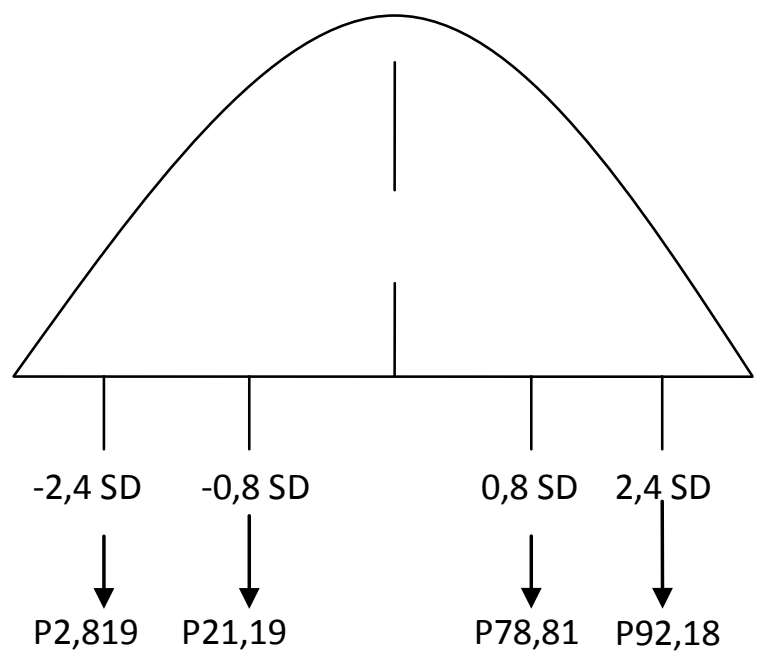

Gambar 1. Kurva Norma Kondisi Fisik 


\section{HASIL DAN PEMBAHASAN}

\section{Hasil}

Data yang diperoleh dari penelitian itu diolah dan dianalisis dengan statistik. Adapun rangkuman deskripsi data secara keseluruhan akan disajikan sebagai berikut:

Tabel 1. Data Hasil Tes Daya tahan, Kecepatan, Kecepatan Reaksi Tusukan, Kekuatan Otot Tungkai Atlet Anggar Kota Surakarta 2018.

\begin{tabular}{lcccccc}
\hline Item Tes & Satuan & Jumlah & $\begin{array}{c}\text { Rata- } \\
\text { rata }\end{array}$ & SD & $\begin{array}{c}\text { Nilai } \\
\text { Tertinggi }\end{array}$ & $\begin{array}{c}\text { Nilai } \\
\text { Terendah }\end{array}$ \\
\hline $\begin{array}{l}\text { Shadow } \\
\text { fencing }\end{array}$ & menit & 158,22 & 4,65 & 3,01 & 12,25 & 1,15 \\
\hline $\begin{array}{l}\text { Step test } \\
\text { Reaksi } \\
\text { Tusukan }\end{array}$ & detik & 232,23 & 3,75 & 0,98 & 5,63 & 9,17 \\
\hline $\begin{array}{l}\text { Split squat } \\
\text { jump }\end{array}$ & kali & 1171 & 28,56 & 13,15 & 58 & 13 \\
\hline
\end{tabular}

Berdasarkan data pada tabel 1 dapat diketahui bahwa pada item shadow fencing diperoleh skor tertinggi sebesar 12,25 menit, skor terendah sebesar 1,15 menit dan nilai rata-rata sebesar 4,65 menit. Pada item step test diperoleh skor tertinggi sebesar 5,63 detik, skor terendah sebesar 9,17 detik dan nilai rata-rata sebesar 3,75 detik. Pada item reaksi tusukan diperoleh skor tertinggi sebesar 0,6 detik, skor terendah sebesar 0,18 detik dan nilai rata-rata sebesar 0,25 detik. Pada item split squat jump diperoleh skor tertinggi sebesar 58 kali, skor terendah sebesar 13 kali dan nilai rata-rata sebesar 28,56 kali.

Perhitungan hasil reliabilitas antara tes dan retes dengan maksud untuk mengetahui tingkat keajegan tes yang diperoleh. Adapun hasil uji reliabilitas yang dilakukan terhadap hasil tes kemampuan fisik atlet anggar Surakarta tahun 2018 adalah sebagai berikut 
Tabel 2. Ringkasan Hasil Uji Reliabilitas Data

No.

Variabel tes

Reliabilitas

Kategori

\begin{tabular}{llcc}
\hline 1 & Shadow fencing & 0,92 & Tinggi \\
\hline 2 & Step test & 0,92 & Tinggi \\
\hline 3 & Kecepatan reaksi tusukan & 0,74 & Kurang \\
\hline 4 & Split squat jump & 0,96 & Sangat Tinggi \\
\hline
\end{tabular}

Berdasarkan data pada tabel 2 dapat diketahui hasil uji reliabilitas pada kategori tinggi (variabel tes shadow fencing dan step test), kategori kurang (variabel kecepatan reaksi tusukan) dan kategori sangat tinggi (variabel split squat jump).

Dalam mengolah dan menganalisis data hasil tes kemampuan fisik ini tiap variabel diubah menjadi T-score. Hasil tes yang diperoleh sampel diberi penilaian sesuai dengan T-score yang telah disusun.

Selanjutnya dilakukan analisis dengan menyusun norma klasifikasi tingkat kemampuan fisik. Adapun hasil pengklasifikasian dan penyusunan norma penilaian terhadap nilai tital T-score kemampuan fisik atlet anggar Surakarta tahun 2018 yang dilakukan dalam penelitian ini adalah sebagai berikut:

Tabel 3. Hasil Pengklasifikasi dan Norma Penilaian Kondisi Fisik Atlet Anggar Kota Surakarta Tahun 2018.

\begin{tabular}{|c|c|c|c|}
\hline Range & Kategori & Jumlah Subyek & $\begin{array}{c}\text { Jumlah Subyek } \\
\text { dalam } \%\end{array}$ \\
\hline$>233$ & Sangat Baik & 2 & $6 \%$ \\
\hline $222-232$ & Baik & 4 & $12 \%$ \\
\hline $180-221$ & Sedang & 22 & $64 \%$ \\
\hline $159-179$ & Kurang & 5 & $15 \%$ \\
\hline$<158$ & Sangat Kurang & 1 & $3 \%$ \\
\hline \multicolumn{2}{|c|}{ TOTAL } & 34 & $100 \%$ \\
\hline
\end{tabular}


Berdasarkan data pada tabel 3, dapat diketahui bahwa diperoleh 2 $(6 \%)$ atlet pada kategori sangat baik, 4 (12\%) atlet pada kategori baik, 22 (64\%) atlet pada kategori sedang, 5 (15\%) atlet pada kategori kurang, dan $1(3 \%)$ atlet pada kategori kurang sekali. Kategori klasifikasi tersebut disajikan dalam bentuk histogram sebagai berikut:

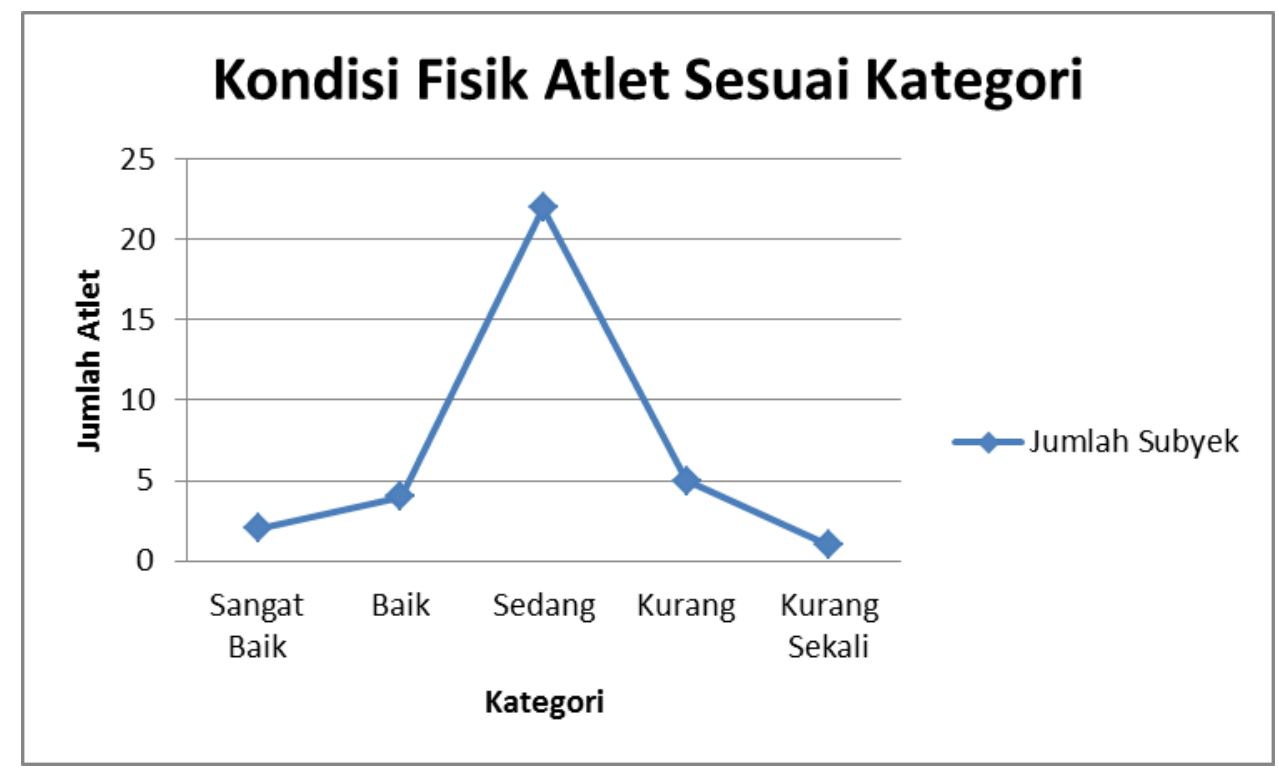

Gambar 2. Kondisi Fisik Atlet Sesuai Kategori

Gambar 2 menunjukkan tingkat kondisi fisik atlet anggar Kota Surakarta tahun 2018 berada pada kategori sedang dengan jumlah sebanyak 22 atlet. Apabila dibedakan berdasarkan jenis kelamin, maka dapat ditunjukkan pada gambar berikut: 


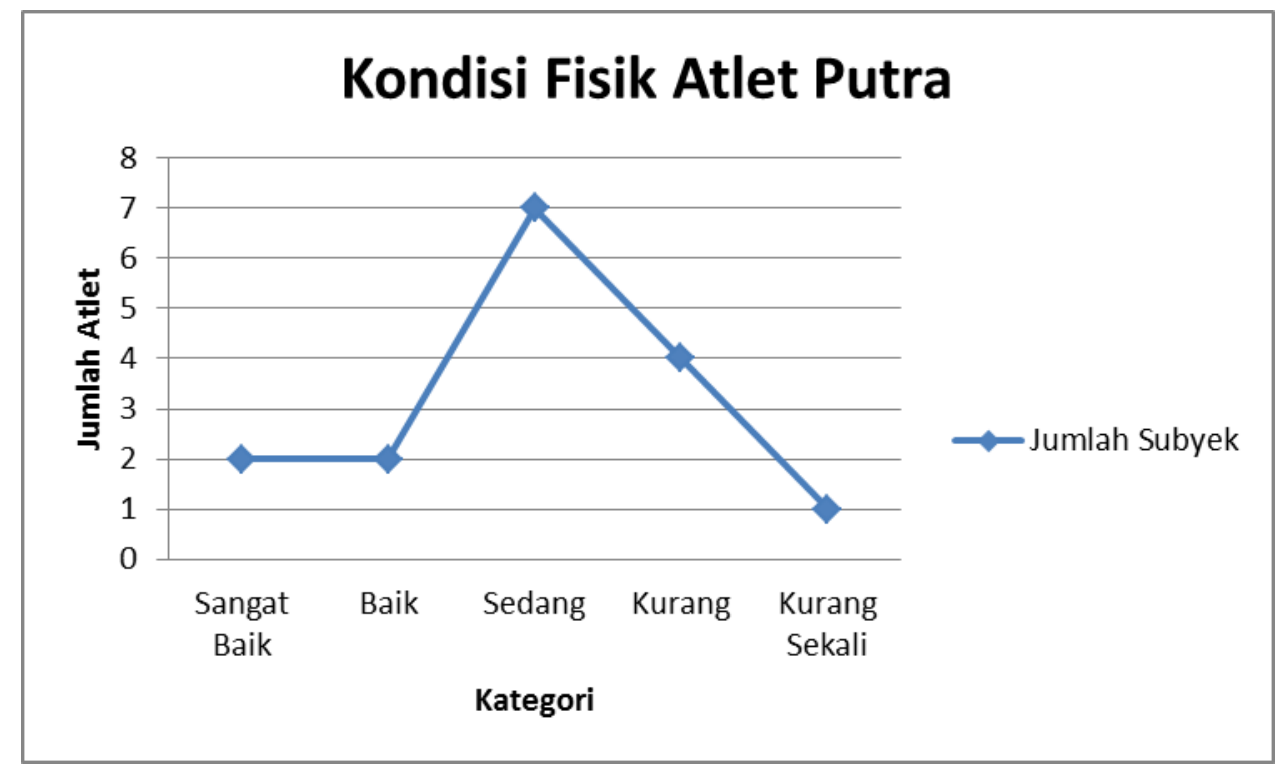

Gambar 3. Kondisi Fisik Atlet Putra

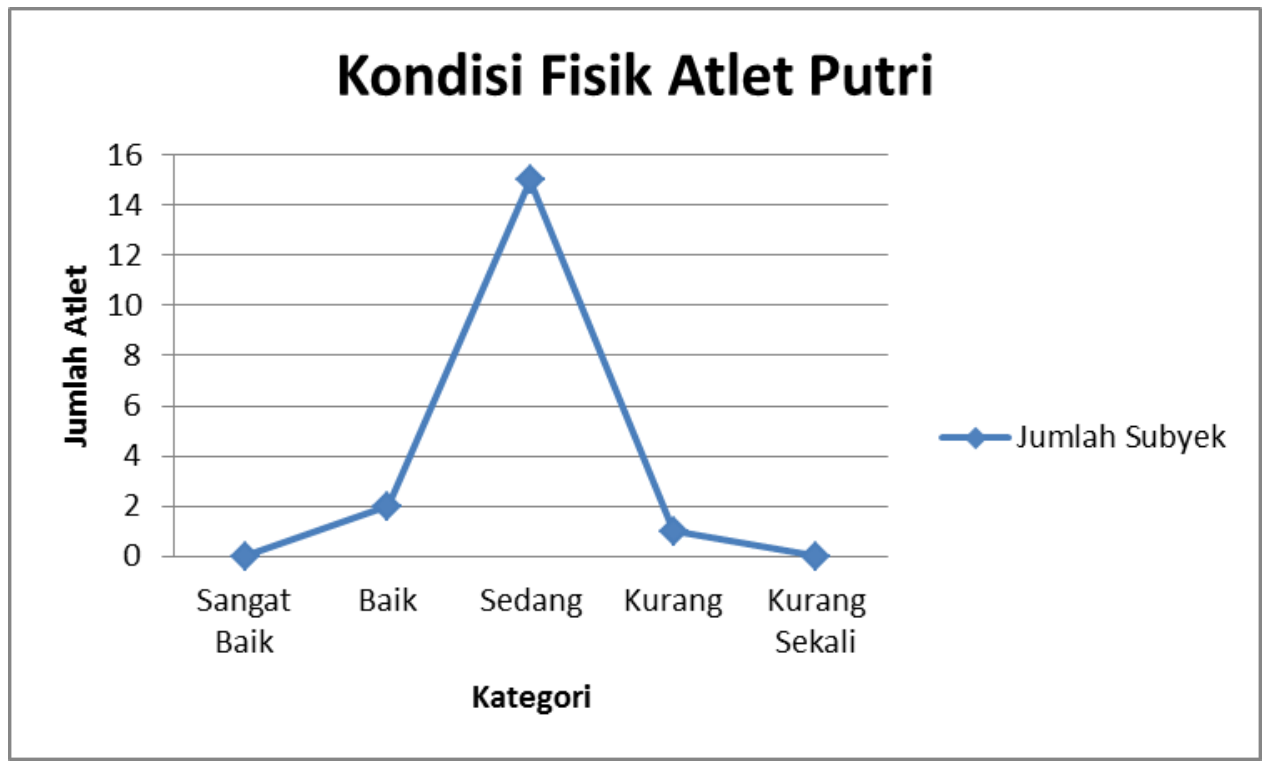

Gambar 4. Kondisi Fisik Atlet Putri

Berdasarkan gambar 3 dapat disimpulkan kondisi fisik atlet putra dalam kategori sedang. Sedangkan pada gambar 4 dapat disimpulkan kondisi fisik atlet putri dalam kategori sedang.

\section{Pembahasan}

Tujuan dari penelitian ini adalah untuk mengetahui tingkat kondisi fisik atlet anggar Kota Surakarta tahun 2018 sekaligus menyusun norma baru tentang kondisi fisik atlet anggar. Adapau item kondisi fisik yang 
menjadi instrumen dalam penelitian ini adalah 1) daya tahan, 2) kecepatan, 3) kecepatan reaksi, dan 4) kekuatan otot tungkai.

Hasil penelitian menunjukkan bahwa secara umum hasil tes kondisi fisik atlet anggar kota Surakarta tahun 2018 termasuk dalam kategori sedang dengan jumlah sebanyak 22 atlet. Hasil yang menunjukkan pada kategori sedang dipengaruhi oleh banyak faktor. Faktor yang mempengaruhi kondisi fisik adalah: 1) faktor latihan, 2) faktor prinsip beban latihan, 3) faktor istirahat, 4) faktor kebiasaan hidup yang sehat, 5) faktor lingkungan dan, 6) faktor makanan (Pujianto, 2015). Menurut Sajoto dalam Mahendra (2014) menyatakan bahwa pembinaan kondisi fisik dalam olahraga bahwa kalau seseorang atlet ingin berprestasi harus memiliki kondisi fisik seperti: kekuatan (strength), daya tahan (endurance), daya ledak otot (muscular power), kecepatan (speed), koordinasi (coordination), fleksibilitas (flexibility), kelincahan (agility), keseimbangan (balance), ketepatan (accuracy), reaksi (reaction).

Kondisi fisik sejatinya dapat ditingkatkan melalui latihan. Seorang atlet akan mengembangkan keterampilannya dari teknik dasar ke teknik yang lebih lanjut apabila memiliki fisik yang cukup (Hinda Zhannisa \& Sugiyanto, 2015). Memiliki kemampuan kondisi fisik yang prima membutuhkan proses latihan yang panjang (Harsono \& Sugiantoro, 1988). Menurut Sajoto dalam Pujianto (2015) dalam latihan kondisi fisik, dapat dibedakan menjadi dua macam program latihan. Pertama, program latihan peningkatan kondisi fisik baik perkomponen maupun secara keseluruhan. Kedua, program latihan mempertahankan kondisi fisik, yaitu program latihan yang disusun sedemikian rupa sehingga dengan program tersebut diharapkan akan berada dalam status kondisi puncak sesuai dengan kondisi fisik yang dibutuhkan untuk cabang olahraga yang bersangkutan dalam suatu turnamen atau pertandingan tertentu.

Sementara itu, menurut Burgess (1993) menyatakan bahwa,"The main components of physical conditioning are cardiovascular endurance, flexibility, muscular strength and endurance, and skill development. The cardiovascular system is conditioned most effectively by active exercise 
such as running, swimming, or bicycling, and to a lesser degree, by weight resistance exercise and arm-cranking", dengan maksud kurang lebih adalah komponen utama kondisi fisik adalah daya tahan kardiovaskular, fleksibilitas, kekuatan otot dan daya tahan, dan pengembangan keterampilan. Sistem kardiovaskular dikondisikan paling efektif oleh latihan aktif seperti berlari, berenang, atau bersepeda, dan ke tingkat yang lebih rendah, dengan latihan beban berat dan lengan-engkol.

Daya tahan adalah kemampuan untuk bekerja atau berlatih dalam waktu yang lama tanpa mengalami kelelahan (Maya Kurnia \& Kushartanti, 2013). Daya tahan adalah kemampuan otot dalam berkontraksi atau bekerja dengan waktu yang relatif lama. Dengan daya tahan yang baik, performa atlet akan tetap optimal dari waktu ke waktu karena memiliki waktu menuju kelelahan yang cukup panjang (Prakoso \& Sugiyanto, 2017). Daya tahan sangat dibutuhkan karena apabila seorang atlet mempunyai daya tahan yang buruk atlet tersebut tidak akan mampu bertahan selama pertandingan berlangsung, karena dalam pertandingan anggar memerlukan waktu 3x3 menit untuk setiap satu kali bermain padahal untuk mencapai final diperlukan beberapa kali bertanding sehingga daya tahan yang baik sangat dibutuhkan.

Kekuatan secara umum adalah kemampuan kontraksi seluruh system otot dalam mengatasi tahanan atau beban (Hinda Zhannisa \& Sugiyanto, 2015). Kekuatan memegang peranan penting dalam cabang olahraga anggar, terutama kekuatan otot tungkai. Kekuatan otot tungkai sangat dibutuhkan karena tumpuan (tungkai) dalam bermain anggar harus tetap aktif bergerak untuk mendukung gerak serang maupun gerak bertahan. Sementara kekuatan yang didukung oleh kecepatan, akan menghasilkan gerak serang dan gerak bertahan yang baik. Kecepatan adalah kemampuan otot atau sekelompok otot untuk menjawab rangsang dalam waktu secepat atau sesingkat mungkin (Hinda Zhannisa \& Sugiyanto, 2015). Kecepatan yang dibutuhkan dalam anggar salah satunya adalah kecepatan reaksi tusukan. Kecepatan reaksi tusukan 
diperlukan untuk melakukan ketepatan serangan maupun pada saat menangkis serangan lawan ataupun mengelak dari serangan lawan.

Hasil penelitian ni menjelaskan bahwa kondisi fisik merupakan bagian yang sangat penting dalam mencapai prestasi. Tingkat kondisi fisik yang baik, akan mengarahkan atlet mengembangkan teknik dasar menuju ke teknik lebih lanjut.

\section{KESIMPULAN DAN SARAN}

Berdasarkan hasil penelitian dan hasil analisis data yang telah dilakukan dapat disimpulkan bahwa tingkat kondisi fisik atlet anggar Surakarta tahun 2018 dapat dikategorikan sedang. Berdasarkan hasil penelitian diharapkan dapat berguna sebagai informasi bagi pelatih dalam rangka meningkatkan prestasi.

1. Atlet dapat menambah latihan sendiri diluar jam latihan.

2. Pelatih dapat menempuh perbaikan dan peningkatan fisik yang dimiliki oleh atlet.

\section{UCAPAN TERIMA KASIH}

Kami tim peneliti mengucapkan terima kasih kepada Direktorat Riset dan Pengabdian Kepada masyarakat, Kementrian Riset, Teknologi, dan Pendidikan Tinggi yang telah mendanai kegiatan ini, sehingga kegiatan Penelitian Dosen Pemula (PDP) dapat terselesaikan dengan membawa manfaat bagi masyarakat umum.

\section{DAFTAR PUSTAKA}

Burgess, E. M. (1993). Physical fitness : A Guide for Individuals with Lower Limb Loss. Diane Pub Co. Retrieved from https://books.google.co.id/books/about/Physical_Fitness.html?id=4n $\mathrm{nXgaEuNgsC \& redir \_ esc}=\mathrm{y}$

Hanief, Y. N., Puspodari, P., \& Sugito, S. (2017). Profile of physical condition of Taekwondo Junior Athletes Pusklatkot (Training centre) Kediri city year 2016 to compete in 2017 east java regional Competition. International Journal of Physiology, Nutrition and Physical Education, 2(2), 262-265. Retrieved from http://www.journalofsports.com/archives/2017/vol2/issue2/PartE/22-19

Harsono, M., \& Sugiantoro, G. (1988). Latihan Kondisi Fisik. Bandung: 
ANKOR-MENPORA-(SORI).

Hinda Zhannisa, U., \& Sugiyanto, F. (2015). Model Tes Fisik Pencarian Bakat Olahraga Bulutangkis Usia Di Bawah 11 Tahun Di Diy. Jurnal Keolahragaan, 3(1), 117-126.

Kurniawan, F. (2010). Mengenal Cabang Olahraga Klasik, Anggar. Yogyakarta: FIK UNY.

Mahendra, I. R. (2014). Faktor Kondisi Fisik Dominan Penentu Prestasi Bermain Tenis Meja (Analisis Faktor Fleksibilitas Pergelangan Tangan, Fleksibilitas Pinggul, Waktu Reaksi, Koordinasi Mata Tangan, Kelincahan , dan Power Otot Lengan Pada Mahasiswa Pembinaan Prestasi Tenis Mej. Universitas Sebelas Maret Surakarta.

Maya Kurnia, B. M., \& Kushartanti, W. (2013). Pengaruh Latihan Fartlek Dengan Treadmill Dan Lari Di Lapangan Terhadap Daya Tahan Kardiorespirasi. Jurnal Keolahragaan, 1(1), 72-83. Retrieved from https://journal.uny.ac.id/index.php/jolahraga/article/view/2347/1949

Pertiwi, C. T. Juni. (2012). Profil Kondisi Fisik Atlet Anggar di Kabupaten Purworejo Jawa Tengah. Universitas Negeri Yogyakarta.

Prakoso, G. P. W., \& Sugiyanto, F. (2017). Pengaruh Metode Latihan dan Daya Tahan Otot Tungkai terhadap Hasil Peningkatan Kapasitas Vo2max Pemain Bola Basket. Jurnal Keolahragaan, 5(2), 151-160. Retrieved from https://journal.uny.ac.id/index.php/jolahraga/article/view/10177/9869

Pratama, B. A. (2015). Jurnal Sportif. Jurnal SPORTIF : Jurnal Penelitian Pembelajaran, 1(1), 74-80. Retrieved from http://ojs.unpkediri.ac.id/index.php/pjk/article/view/576

Pratiwi, F. Z., Setijono, H., \& Fuad, Y. (2018). Effect of Plyometric Front Cone Hops Training and Counter Movement Jump Training to Power and Strenght of Leg Muscles. Jurnal SPORTIF: Jurnal Penelitian Pembelajaran, 4(1), 105-119. https://doi.org/10.29407/js_unpgri.v4i1.12073

Pujianto, A. (2015). Profil Kondisi Fisik dan Keterampilan Teknik Dasar Atlet Tenis Meja Usia Dini di Kota Semarang. Journal of Physical Education, Health and Sport, 2(2), 38-43. https://doi.org/10.1016/j.ejogrb.2012.06.022

Sugiyono. (2011). Metode Penelitian Kuantitatif dan Kualitatif dan R\&D. Bandung: Alfabeta. 